\title{
海水の結水機構と強度特性 \\ GROWTH MECHANISMS AND MECHANICAL PROPERTIES OF SEA ICE
}

\author{
佐伯 浩* \\ By Hiroshi SAEKI
}

\section{1. まえがき}

海水の影響を受ける海域は, 全海洋面積の $10 \%$ 程度 といわれている．冬期間結氷するような寒冷地の海岸・ 海洋ではバルト海などごく一部の海域を除くと, 冬期間 ほとんどすべての人間の活動が停止するのが常であっ た. 日本近海ではオホーツク海がその例で，1月下旬か ら 2 月上旬に北部才ホーツク海から冬期の季節風と東力 ラフト海流に乗って移動してくる流水と沿岸域の結水に よりオホーツク海の約 $70 \%$ は海水で覆われ, 北海道の オホーツク海沿岸ではすべての海での活動が停止する. そのため海水に関する研究も, 海水の物性の面からの研 究, あるいは, 地球規模の気象に及ぼす海水の効果といっ た地球科学の面からの研究が主であった. しかし, 一部 には，海上運輸・海上警備の必要性から砕水船に関する 研究の歴史は比較的古く, 砕水船と海水の相互作用の研 究はすでに多くの研究成果を挙げている.これに対して, 河川や湖沼の水理構造物之淡水水の相互作用について は,その研究成果そのものは少ないが経験的な積重ねで, 航路標識, 栈橋等が多数建設されてきている. しかし, 最近になって海水に関する工学的な研究が世界各国で非 常に活発になってきているが，その背景にば次のような 目的があると思われる.

1）オイルショック以来のエネルギー危機に対応し て, 寒冷地の海岸, 海洋底にその存在が確認されている 石油・ガスの採掘装置あるいは, それら資源の探査装置 の海水に対する設計法を確立することおよび海水に対し て有効で経済的で安全な構造物の開発のため

2） 寒冷地の開発に伴う航路維持のためと, 寒冷地に

* 正会員 工博 北海道大学教授 工学部土木工学科 （厂060 札熀市北区北 13 条西 8 丁目）
ある国々の経済活動の活発化と国際化に伴う物資輸送に 対する航路維持のため, 新しい型式の砕水船, 砕水貨物 船, 砕水タンカー, 耐水タンカー等の設計法を確立する ため

3）海水盤を氷上滑走路，水上軌道，水上貯蔵基地等 のように水盤を交通施設あるいは貯蔵施設等に利用する ためと，人工氷床として海底下の埋蔵エネルギ一資源の 探査，掘削施設として利用するため

4）ある限られた海域，あるいは海岸域の海水の動き を制御し，養殖施設や養殖水産資源を保護する必要があ るため

現在は上述したような諸問題の解決に迫られているこ とから, 海水の成長機構, 海水の強度特性の解明も重要 となってきている．特に，海水と海岸・海洋構造物間の 相互作用については, 海水の厚さ, 海水の圧縮強度, 曲 げ強度, せん断強度それに弾性率やポアンン比といった 弾性諸定数の特性が明らかにされねばならないし,また， 海水之種々の構造物間の摩擦係数や涷着強度も重要であ る. 本研究は主として海水の結水および成長機構と海水 の強度特性についての現在までの研究成果のとりまとめ と今後の展望について述べることにする.

\section{2. 海水の結水機構}

\section{（1） 海水の結水温度}

海水は含まれる塩分量によって結水温度が異なるし， 結水機構が異なっている. 海水の結水温度は, クヌード セン，シュレイキンにより1次式で示される.

$T_{f}=0.008-0.0527 S-0.00004 S^{2}-0.0000004 S^{3}$

ここに, $S$ : 塩分量 $(\% \circ), T_{f}:$ 結水温度 $\left({ }^{\circ} \mathrm{C}\right)$

これに対して, 海水の最大密度を示す水温 $T_{o \max }$ は次式 


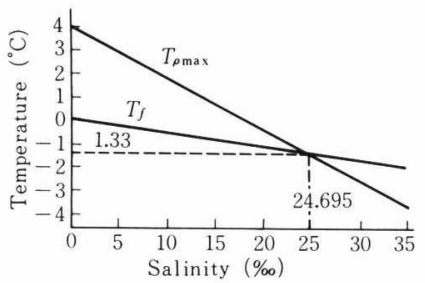

図一1 海水の結水温度および最大密度と 海水中の塩分量の関係

で示される.

$T_{\text {omax }}=3.95-0.2 S-0.0011 S^{2}-0.00002 S^{3} \cdots(2)$ この両式を図示したものが図一1である. 図より塩分量 が $24.695 \%$ 以下では, 最大密度を示す水温 $T_{\rho \max }$ が $T_{\rho \max }>T_{f}$ なので, 海水温が $T_{\rho \max }$ より高い範囲までは 冷却されるに従い対流により鉛直方向の水温が一定にな るが， $T_{\rho \max }$ より表層が低い温度になってくると，対流 は止まり熱伝導により熱が移動する，それに対して，塩 分量 $S$ が $S>24.695 \%$ の場合は， $T_{f}>T_{\text {omax }}$ であるの で水温は結水温度に対するまで鉛直循環し, 表層から下 層まで一様に結水温度に達してから表層から結水が開始 する. 一方, 寒冷地の海洋の塩分量は $S \geqq 32 \%$ なので, その凍結の仕方は後者に属することになる.

\section{（2）海水の結水過程}

海水の結水過程は, 海水が表層から水底まで一様に結 氷温度に対してから表層から結水が始まる。このとき， ごく表層では過冷却の状態にあり，これが核となる微粒 氷晶の生成に寄与するといわれている. 結水初期にはま ず多くの針状の水片が形成され，これを板状の薄水が埋 めるというようにして結氷が進み，これを Sheet Iceと よんでいる.この針状の結晶水片は大気温度 $-20^{\circ} \mathrm{C} て ゙$ $1 \sim 3 \mathrm{~cm},-50{ }^{\circ} \mathrm{C}$ で $7 \sim 9 \mathrm{~cm}$ 程度にまで成長するこ とがある、これは低温室内での結水の様子であるが, 実 際の海面では, 波浪や対流, 移流の影響で Sheet Ice は 形成されにくい．これは生成された針状水片や板状薄水 片は波浪等により破壊され, 分裂・結合を繰り返し, Pancake Ice とよばれる蓮葉状の円くまわりがめくり上 がった氷板が形成される.このPancake Ice で海面が 覆われると, 急激に波浪が減衰し,このPancake Ice の間を埋めるように結水が起こり, 海面全体を覆う Ice Field を形成する．実際の海面では降雪があるため結水 機構はより複雑である.たとえば,海水温が氷点下になっ た状態で降雪があると, 水面に落下した雪の結晶は融解 することなく海水面に浮かぶ。これにより, 海面は急に 穏やかになり，そのまま結氷が始まることがある．この ように雪まじりの水をその結晶構造から雪水り

(Granular Ice) とよんでいて, 図一2 に示すように氷 中に雪の粒子が残っている.この Granular Ice の下層

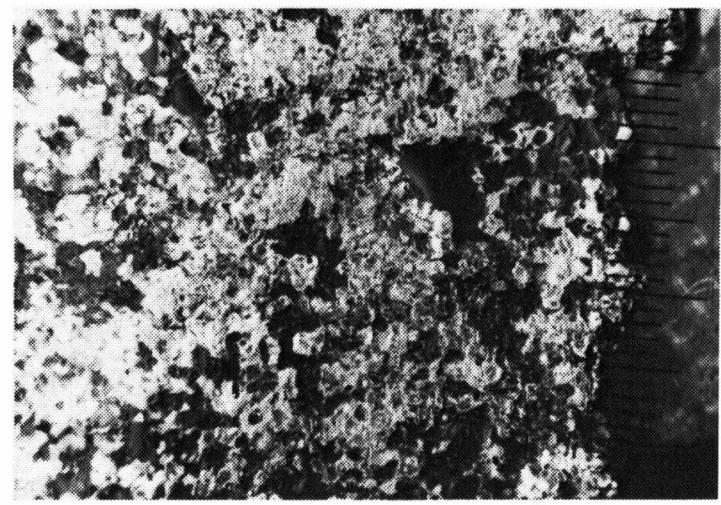

図一2 Granular Ice の結晶構造（水平断面）

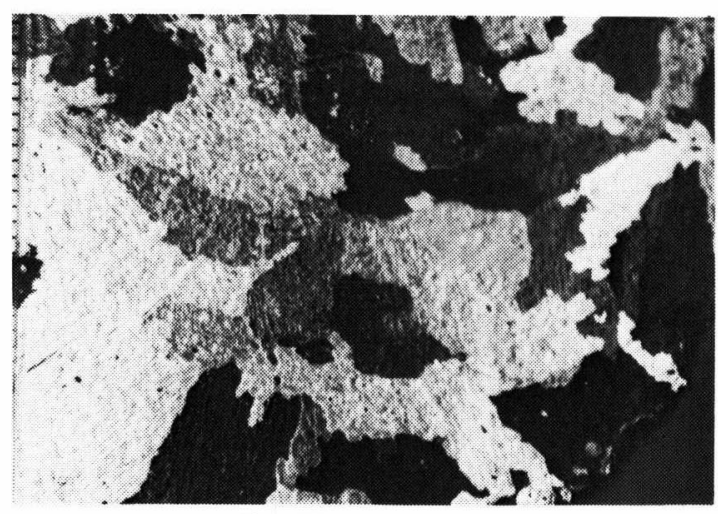

図一3 Columnar Ice の結晶構造（水平断面）

に，図一3に示すようにいわゆる Calumnar Ice が成長 することになる.また,ある場合には通常の結水が始まっ た後に降雪があると, 雪の重みで水盤は沈み込むが, 海 氷の透水係数が比較的大きいため, 海水が表層にしみ上 がり，雪とともに結氷することになり，この場合も氷盤 の表層部は Granular Ice が形成される. 以上述べたよ うに実際の海水は, 成長時に降雪等の影響を受けるため, その氷厚増加の過程は非常に複雑である。一般的な海水 の状態を図一-4 長に伴い下面で大量のブラインを氷中に取り込み, 水厚 の増加とともに塩分を失っていく.この水厚の正確な予 測を行うためには, 水厚の成長に伴う海水中の塩分量の 変化を十分に考慮せねばならない.

\section{（3）水厚增加の理論}

氷の水厚増加に関する研究は熱伝導の問題に帰着す る. 水の成長に関する理論では, 古くは Stefan ${ }^{3)} ゃ$ Neumann ${ }^{4 /}$ の研究が報告されているが,これらの研究 は淡水水の成長である. 両研究において, Stefan の場 合は, 水の表面は大気温度に常に等しく水盤の底では結 水温度の $0{ }^{\circ} \mathrm{C}$ で, 水中の水温は常に $0{ }^{\circ} \mathrm{C}$ との条件で の解であり, Neumannの場合は, Stefanの境界条件を 


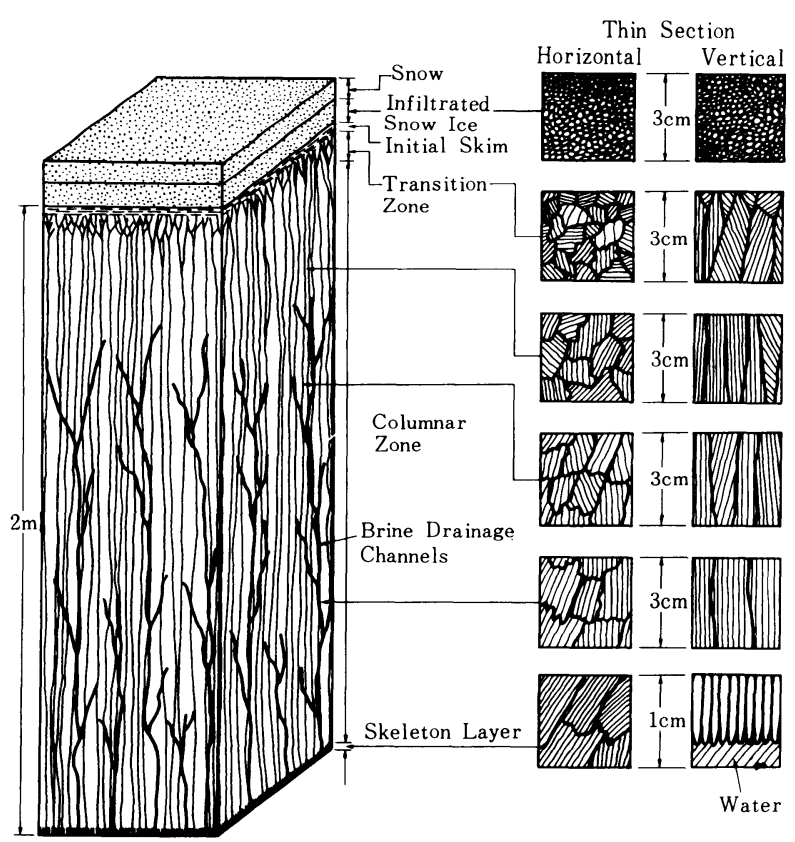

図一4 海隶の構造 (Schwarz, 1977)

現実に合うように水の表面は大気温度に等しく，水底で は水の最大密度を示す $4{ }^{\circ} \mathrm{C}$, 水の下面では結水温度と いう条件で，水盤中と水中の熱伝導式を界面で接続する 手法で解を求めている. しかし係数は異なるものの, 両 式とも結水開始時から $t$ 時間後の水厚は次式で示され る.

$$
h=K^{\prime} \cdot(t)^{1 / 2}
$$

ここに, $h$ : 水厚, $K^{\prime}$ : 気温, 氷の融解潜熱, 密度, 熱 伝導率, 温度伝導率で決まる定数

この式（3）を変形すると次式で示される.

$$
h=K \cdot\left(\sum T\right)^{1 / 2}
$$

$\Sigma T$ は積算寒度である. $\sqrt{K}$ を一般的に氷厚係数とよ んでいる.つまり両理論とも基本的には，氷厚増加は積 算寒度の $1 / 2$ 乗に比例することを示している．また，海 水の水厚の増加については, 福富らの研究5), Tabata ${ }^{6)}$ らの研究から, 海水に対しても式 (4) が満足されてい ることを示した。しかし，実際の現象の観察から結水初 期の海水の成長については, 成長に伴う水中の塩分量の 変化とそれが氷厚成長に及ぼす効果が重要なことが Zubov や Malmgren や小野泉によって報告され，海水成 長に対する理論モデルが種々の研究者により提案され た ${ }^{10) ~ 12)}$. 長谷美 ${ }^{13)}$ は, 海水の結水時の塩分捕捉量につ いては, Weeks らの結果を用い(4)，また成長に伴って， 水の中のブラインの温度が徐々に低下するときのブライ ン内の水の析出による体積増加のためのブラインの放出 量はUntersteiner の結果を用いて, 水厚増加のシミュ

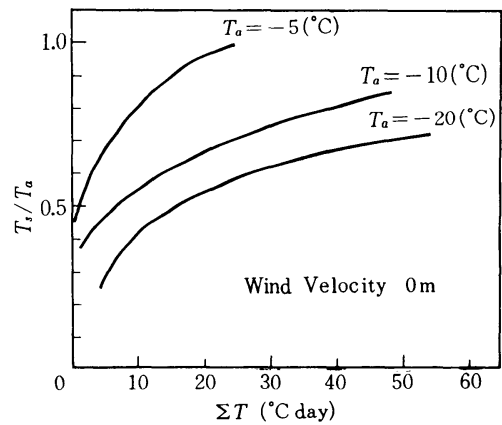

图一5 䅡算寒度と氷盤の表面温度の関係

(Saeki et al. 1978)

レーションを行った。計算結果は実測結果と必ず しもよい一致を示したわけではないが, 結水初期 においては式（4）に示されているような積算寒 度の $1 / 2$ 乗にはならないことが示されるととも に，その理由として，結水初期には海水からの熱 の補給もあり, 海氷の表面温度はなかなか気温に 一致していないことを明らかにしている. 佐伯も 同様な実験を行っていて，その結果を図一5に示 す. $T_{s}$ は氷盤の表面温度, $T_{a}$ は大気の温度, 横軸は積 算寒度で, 気温が低いほど氷盤の表面温度は気温に一致 するのに時間がかかる.このため, 結水初期においては 氷厚 $h$ は積算寒度の $1 / 2$ 乗に比例しないことになる.

以上, 海水の結水機構と成長について述べてきたが, 海 氷の成長機構そのものも重要ではあるが，それ以外に大 気と海面, 海水間の熱交換過程も今後の研究が望まれて いる. 工学的にみるならば，海水の結氷にかかわる諸問 題は, 模型実験のための水の作製，実際の海水の水厚の 推定に関連している. 海水の影響を受ける海域における 海岸・海洋構造物の設計, 砕水船の航路選定にあたって は, 的確な水厚を推定することが重要である. 気象条件 から水厚を推定する方法, 実験值, 観測値から得られた 実験式から推定する方法が今までとられてきているが, これは, 水海域での水厚の測定が非常に困難だからで あった．しかし，現在は，レーザープロファイ・ラー ${ }^{151,161}$ や電磁波を使った氷厚測定法や赤外線と気温から水厚を 推定する方法が開発され始めていて，これら新しい測定 法の一層の進歩が望まれるところである.

\section{3. 海水の強度特性}

海水が構造物に作用するとき, 最大の氷力は, 水盤そ のものが破壊するときに発生する.よって各種の構造物 に作用する氷力を求めるためには, 海氷の強度および弾 性定数が与えられねばならないので, 海水強度を明らか にすることは設計にとっても非常に重要である．海水の 
強度は，海洋の性質がきわめて複雑で，等方等質とはい いがたいこともあって，強度に及ぼす影響因子も非常に 多い.ここでは，構造物の設計にとって重要な，海水の 一軸圧縮強度と曲げ強度それに弾性率とポアンン比につ いて最近の研究現況と今後の研究展望について述べるこ とにする

\section{（1） 海氷の強度試験方法}

ほとんどすべての材料がそうであるように, 強度試験 をする場合，材料供試体の形状・寸法と試験方法によっ て異なった強度を示す，淡水水も含めて，水の強度試験 方法についてはいまだ完全な標準強度試験方法は確立し ていないのが実情である．この理由の 1 つは, 過去に行 われた氷の試験が主として物性の面からが主であって, 河川や湖沼それに海岸の構造物の氷力に対する設計を対 象としたものでなかったためである. しかし, 最近の水 工学あるいは氷に対する技術の発展に伴い, 標準強度試 験法の確立の要求が強まり, 国際水理学会 (IAHR) の 水問題に関する委員会の強度試験方法に関する作業部会 で試験方法に対する大枠が提案されている ${ }^{17), 18)}$. それに よると，一軸圧縮強度試験については，供試体形状は円 柱で直径 $\phi$ は $75 \mathrm{~mm}$ 以上, 径 $\phi$ と高さ $l$ の比 $l / \phi$ は $l / \phi \geqq 2.5$ が望ましいとしていて, 強度試験時の応力速

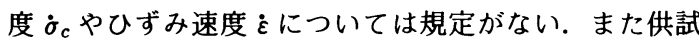
体の載荷板については従来から用いられている鋼板でも よいが，新しい方法として硬質ウレタンを用いることを 推奖しているが, これは載荷時の端面の半径方向の拘束 を減らすことを目的としている。これに対して佐伯 $ら^{191,201}$ は，硬質ウレタンのひずみにより海水供試体のひ ずみの測定が困難であることと硬質ウレタンが温度の影 響を強く受けるとの理由で反論している．また曲げ強度 $\sigma_{r}$ の試験方法については, Frederking \& Häusler ${ }^{21)}$ Lavrov $^{22)}$ の研究成果に基づいて, 桁のスパン長 $l$ は桁 高 $d$ の 7 10 倍にすべきこと, 妳の幅 $b$ は桁高 $d$ の 1 ～2 倍にすべきことと, 平山ら ${ }^{23)}$ の結果をもとに, 析幅 と水のグレインの平均径 $D_{g r}$ の関係にも注意すべきこ とが述べられてはいるが，供試体の絶対的な寸法には言 及していない．このように強度試験方法が不確定である ことが強度の測定結果の相互の比較ができない理由と なっている. 今後は, より詳細な試験方法の規準化, 標 準化に向けての研究が重要となってきている.

\section{（2）海氷強度への影票因子}

海水は純水とブラインポケットそれに気泡より成り 立っている．海水の構造モデルについては, Assur \& Weeks ${ }^{24)}$ が提案したモデルがよく知られている．淡水 氷の場合には，同一の武験条件であれば，強度は氷温に 強く依存するが，それは水温が低いほど，結晶そのもの も，結晶と結晶の界面も強度が強くなる．これに対して
海水の場合は, 気泡や結水時に取り込まれたブラインの 影響も強く受ける. 気泡を全く含まないか, ブライン量 に比べて気泡量が少ない場合には, 強度はブライン量に よって決まる.これは海水が結水する過程で, 海水はそ の成長する結晶と結晶の間に海水を閉じ込めながら成長 する. このときの閉じ込められた海水をブラインといっ ているが，このブラインは結水温度に対応する塩分量を もっている. 水厚が増加するにつれて, あるいは水温の 低下によってブラインの温度は低下していくことにな る. そうなると，その低下した氷温を結水温度とする塩 分量をもつ海水になるためには, ブラインの一部が凍結 して塩分量を高めることになる，そのためブラインの体 積が減ることになる. よって, ブラインの体積が強度に 影響を与えることの中味は氷温の効果もその中に含まれ ていることを意味している. ブラインや気泡が応力に無 関係と考えるならば，海水は多孔質の材料と考えること ができる. 多孔質の材料の場合, 材料の強度は空隙率 (気 孔率）に強く依存することが知られている25). 低緯度の オホーツク海等では, 直達日射量も多く, 結氷後も, 日 中は氷盤の表層部が融解することがあるが，そのため海 氷中には気泡のほかに永方ができたりすることが多 い. そのような場合にはブライン体積と気泡の体積の和 が強度に影響を与えるし，そのような場合には水温も強 度に影響を与える．また，気泡量がブライン量よりもは るかに多くなると海水強度は気泡量と水温あるいは海水 密度 $\rho$ と水温に依存することになる．以上述べてきた ように，海水はコンクリートやモルタル等と同様に複合 材料であり, 強度への影響因子は他の材料に比べて多く, 複雑である. また海水は表層から下層へ向かって成長す るため, 異方性の強い材料であるため, 海水の成長方向 に対する荷重の方向によっても強度に差が出ることにな る. 特に空気量が少なく, 水温が低い場合には異方性が 強くなることが明らかになっている191,26),27).

\section{（3）海水の一軸圧縮強度}

水の一軸圧縮強度がひずみ速度 $\dot{\varepsilon}$ の影響を受けること が Korzhavin ${ }^{28)}$ やCarter \& Michel $^{29)}$ それにFrederking ${ }^{30}$ らの研究成果からよく知られている。 また，Schwarz はバルト海の海水を用いて, 海水の成長方向に平行およ び垂直に荷重をかけて一軸圧縮強度 $\sigma_{c}$ とひずみ速度 $\dot{\varepsilon}$ の関係を各水温別にまとめているが，これには $10 \mathrm{~cm}$ 角の立方体の供試体を用いている。図一6に佐伯らの結 果 ${ }^{20}$ の一部を示す.これは径 $\phi$ が $10 \mathrm{~cm}$, 高さ $l$ が 20 $\mathrm{cm}$ の円筒供試体で載荷板はなめらかな鋼板を用いたも のである．この結果からも明らかなように，一軸圧縮強 度 $\sigma_{c}$ はひずみ速度の影響を受け, $\dot{\varepsilon}$ が $10^{-3} \mathrm{~s}^{-1}$ のオ一 ダーで最大の強度を示しているが,この結果は Schwarz ${ }^{27)}$ らの結果とも非常によい一致を示している 


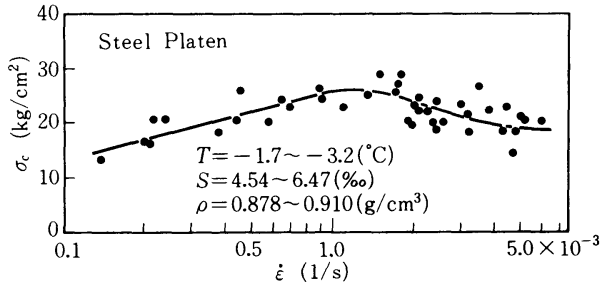

(a)

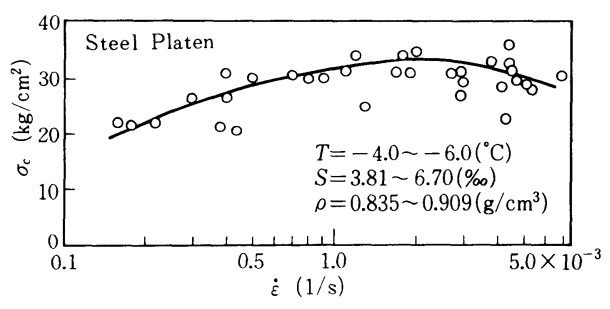

(b)

\section{图一6 海氷の一軸圧縮強度とひずみ速度の関係}

(Saeki et al. 1978)

し, 淡水水で行った Gold \& Krausz ${ }^{31)}$ ，それに Mellor $\& \mathrm{Smith}^{32)}$ の結果ともよい一致を示している.これに対 して, Michel \& Toussaint ${ }^{33)}$ は $-10^{\circ} \mathrm{C}$ の淡水水で行っ た Indentation test の結果をもとに，他の研究者のデー 夕も用いて，ひずみ速度 $\dot{\varepsilon}$ と Indentation Force $\sigma$ の関 係を広範囲にわたって調べているが，その結果が図一7
である. 図からも Michel らは $\dot{\varepsilon}<4 \times 10^{-4} \mathrm{~s}^{-1}$ の範囲を Ductile Region, $\dot{\varepsilon}>10^{-2} \mathrm{~s}^{-1}$ の範囲を Brittle Region とし，この中間を Transition Region と名づけている. これは直接一軸圧縮強度を示しているわけではないが, 海水の一軸圧縮強度とIndentation Test の関係が Linear な関係にあることから, 一軸圧縮強度のひずみ
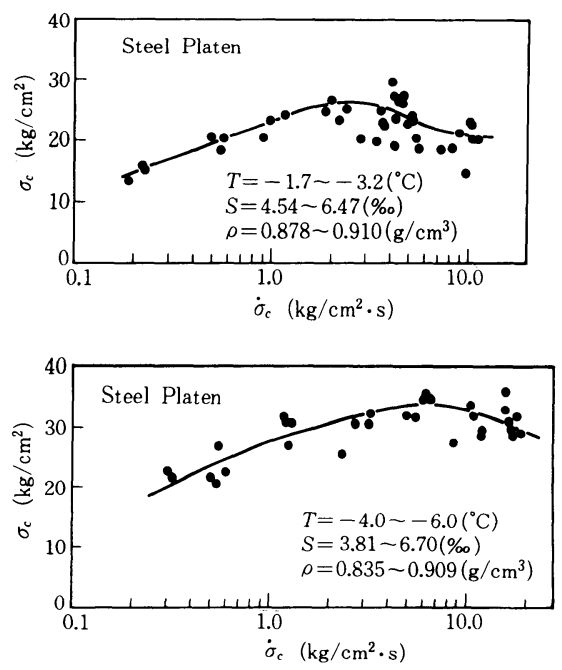

図一8 海隶の一軸圧縮強度と応力速度の関係 (Saeki et al. 1978)

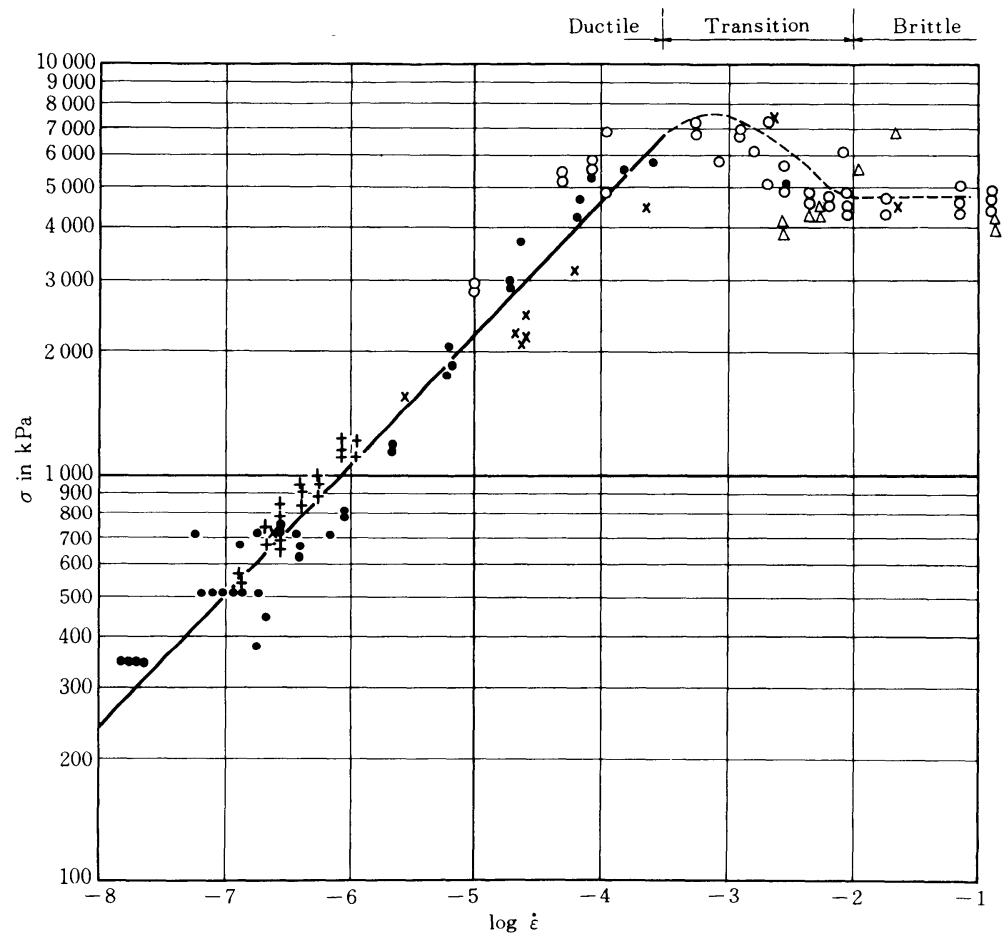

図一7 海氷の Indentation Force とひずみ速度の関係 (Michel \& Toussaint, 1977) 
強度との関係もこれとほぼ同様の関係があると思われ る. 次に一軸圧縮強度 $\sigma_{c}$ と応力速度 $\dot{\sigma}_{c}$ の関係を調へたた ものが図一8である. 図からも明らかなように，一軸圧 縮強度はひずみ速度と同様に応力速度にも依存する。一 軸圧縮強度 $\sigma_{c}$ は, $2 \mathrm{~kg} / \mathrm{cm}^{2} / \mathrm{s}<\dot{\sigma}_{c}<20 \mathrm{~kg} / \mathrm{cm}^{2} / \mathrm{s}$ で最 大の強度を示している.

Peyton $^{26)}$ はクック湾の海水を用いて $\sigma_{c}$ と $\dot{\sigma}_{c}$ の関係 を調べているが, その結果では $\dot{\sigma}_{c} \fallingdotseq 2.0 \mathrm{~kg} / \mathrm{cm}^{2} / \mathrm{s}$ で最 大の水力を示している. その応力速度の範囲は広くはな いが傾向としては佐伯らの結果と一致している．以上の 結果より, 海水の強度はひずみ速度, 応力速度に依存し ていて他の材料と違ってそれらのある值でピーク值を有 し，かつ水温が低いほどそのピークは顥著になることが 明らかとなる．このような事実を十分理解してないと構 造物に作用する氷力を見積るときに大きな誤りをおかす ことになる．前にも述べたように，強度には種々の影響 因子があり，次式で示される

$$
\sigma=f\left(\nu_{b}\right)=f(S, T) \quad \nu_{a} \ll \nu_{b}
$$

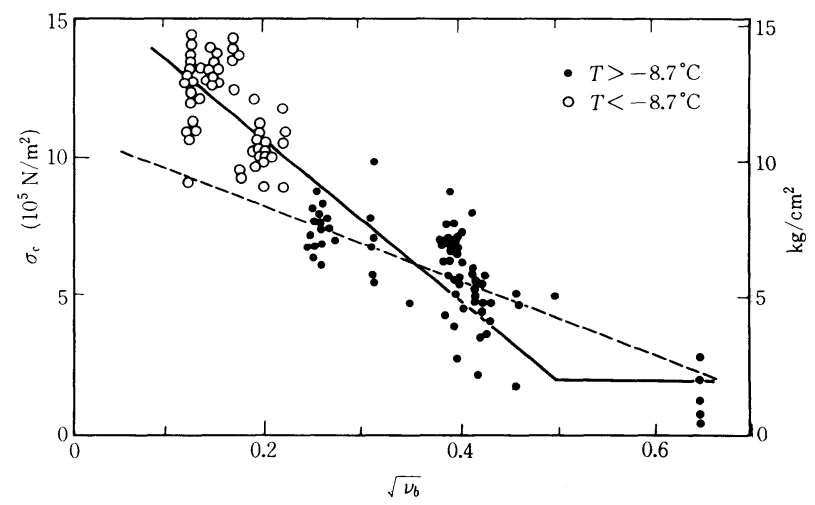

図一9 海米の一軸圧縮強度とブライン母の関係 (Peyton, 1966)

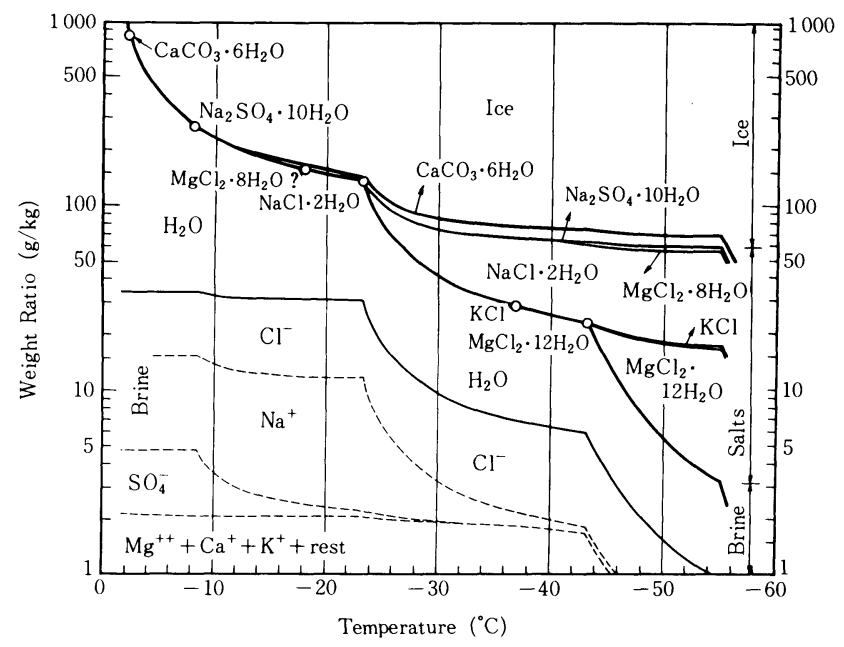

図一10 ブライン中の相变化 (Assur, 1958)

$$
\begin{aligned}
& \sigma=f\left(\nu_{b}+\nu_{a}\right)=f(S, \rho, T) \\
& \sigma=f\left(\nu_{a}, T\right)=f(\rho, T) \quad \nu_{b} \ll \nu_{a}
\end{aligned}
$$

気泡率 $\nu_{a}$ がブライン体積率 $\nu_{b}$ に比べてはるかに少ない 場合には, 前述したように一軸圧縮強度 $\sigma_{c}$ はブライン 体積率 $\nu_{b}$ のみにより決定され式（5）で示される.そ の諸量を図一9に示す. 図中の実線はWeeks \& Assur ${ }^{24)}$ の結果であり，破線はPeyton ${ }^{26)}$ の結果である. Weeks らの結果では $\nu_{b}<0.25$ の範囲では, ブライン量の増加 とともに強度は小さくなる.このブライン量の変化は, 水中のブライン量を表わすだけでなく, 水温の変化に よってブラインの量が変化するときになる. 図一10に 氷温に対するブライン中の相変化を示す ${ }^{24)}$. 海水中のブ ラインは, そのときの水温を結水温度とする塩分量にな る.図一10より明らかなように, 温度の低下とともに ブライン中の水の量がふえて塩分濃度が高まる.これは, 温度の低下とともにブラインポケットの体積が減ること により，強度が強くなることになる．またー $3.0{ }^{\circ} \mathrm{C}$ か ら炭酸カルシウムが析出を始めるがその量は微量であ る. $-23^{\circ} \mathrm{C}$ より低くなると塩類の析出量が 急に多くなり， $-43^{\circ} \mathrm{C}$ より低くなるとさら に析出量がふえてくる.このように，海氷中 のブラインは氷温によってその塩分量が変化 していることになり，ブライン体積の変化に は氷温効果も含まれていることになる.よっ て別の表現をすれば式（5）に示されている ように強度は海水の塩分量 $S$ と水温 $T$ で決 定される.これに対して，オホーツク海南部 海域の海水では, 気泡量もブライン量と同程 度に多く, そのため強度とブライン量の相関 は非常に悪くなり，ブライン量と空気量の和 と強度の相関が強くなってくる.この海水の 空気量の測定は困難であるため，これを簡単 に測定できるもので表わすと式（6）に示さ れているように塩分量 $S$ と水温 $T$ それに海 水の密度 $\rho$ が与えられれば求まることにな る. ブライン量が気泡量に比べて少なくなる と, 海水の強度 $\sigma$ は式 $(7)$ に示されてい

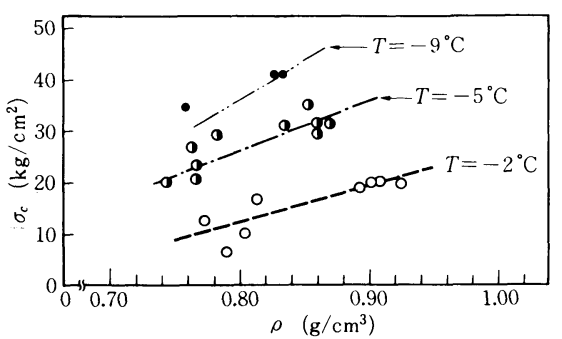

図一11 海水の一軸圧縮強度と水温と密度の関係 (Saeki et al. 1978) 


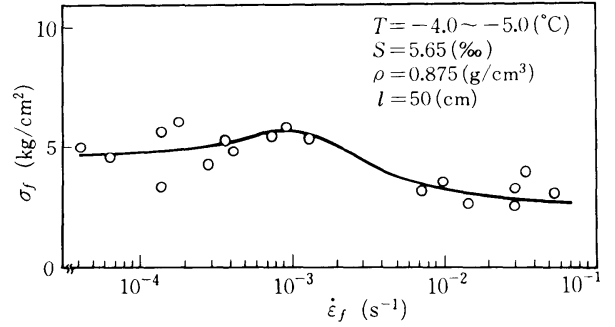

図一12 海头の曲げ強度とひずみ速度の関係

るように $\nu_{a}$ あいは $\rho$ と $T$ で決まることになる. その 結果の一例を図一11に示す.このように, 空気量の多 い海水では, $\rho$ と $T$ で決まることになる. 海水の破壊は, 結晶の界面あるいはグレインの界面で起こるためと，ブ ライン・気泡が必ずしも均一ではないため, 同一の試験 法で同一の条件であってもデー夕は非常に分散が大き い. 現在, 式 (5)，（6)，（7）については明確な適用 区分がなされていないのが実情で, 今後の研究成果に期 待しなければならない. また， $\nu_{a}, \nu_{b}$ は測定が困難であ ることから测定の簡単な $S, \rho, T$ のみで海水強度が表 示されているのが望ましい.

\section{（4）海水の曲げ強度}

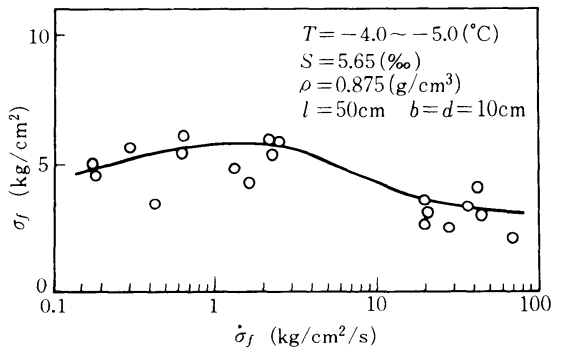

図一13 海氷の曲げ強度と㐫力速度の関係

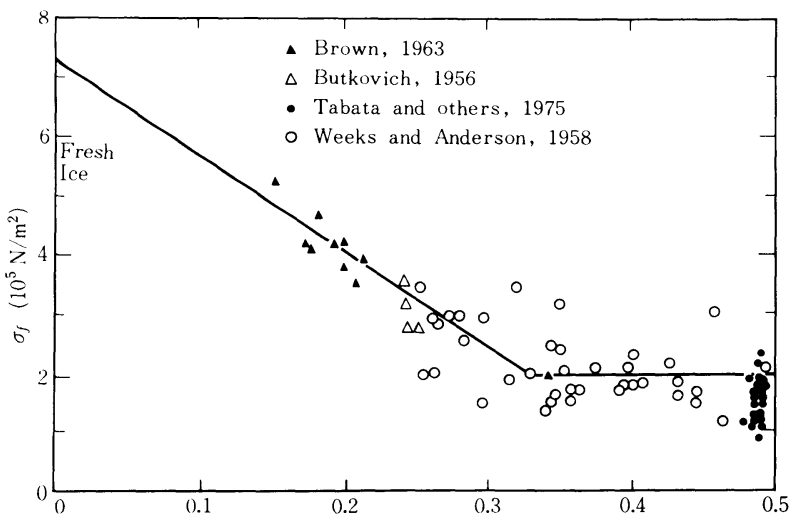

図一14 海水の曲げ強度とブライン量の関係

(Schwarz \& Weeks, 1977)
海水の曲げ強度も, 一軸圧縮強度と同様にひずみ速度, 応力速度に強く影響を受ける. 図一12 に曲げ強度 $\sigma_{f}$ 亡 ひずみ速度 $\dot{\varepsilon}_{f}$ の関係を示す。一軸圧縮強度の場合と同 様に, $\dot{\varepsilon}_{f} \doteqdot 10^{-3} \mathrm{~s}^{-1}$ 近傍で最大の強度を示す。これは水 温に関係なく同様の結果を示す．また， $\sigma_{\boldsymbol{f}}$ と応力速度 $\dot{\sigma}_{f}$ の関係を示したものが図一13であるが，これによる と $1<\dot{\sigma}_{f}<10 \mathrm{~kg} / \mathrm{cm}^{2} / \mathrm{s}$ で最大の強度を示す.これらの ことから海水の曲げ強度試験を行う場合には応力速度, ひずみ速度を十分考慮に入れて試験を行う必要がある し，また構造物と海水間の相互作用に関する問題の解決 にあたってもこのことは十分考慮に入れられねばならな い. 同一の試験法であると，一軸圧縮強度の場合と同様 に空気量が少ない場合には, 強度はブライン量に依存す ることになる.その結果を図-1424)に示す. $\sqrt{\nu_{b}} \leqq 0.33$ の範囲では， $\sigma_{f}$ は $\sqrt{\nu_{b}}$ の増加とともに直線的に低下し， $\sqrt{\nu_{b}} \geqq 0.33$ では $\sqrt{\nu_{b}}$ に関係なく一定の強度を示す ${ }^{24) .34) . ~}$ この結果はDykins らの結果 ${ }^{35)} も$ 同様である.これに対 して, 空気量の多い海水では, 強度 $\sigma_{f}$ は氷温と密度に 依存することになる，曲げ強度の試験については，単純 析による中心点載荷法, 三等分点載荷法それに, 現地水 盤による片持ばり試験, それと同様に現地水盤による耐 荷力試験から求めることができる. 試験方法によって求 まる差より，供試体の寸法効果の方が強度に及ぼす影響 が大きいことが佐伯らの結果で示されている ${ }^{36 !}$.

\section{（5）各強度間の関係}

今まで, 海水の一軸圧縮強度および曲げ強度の特性の 概略について述べてきたが, 海氷強度の試験にあたって 各種強度を求めることは時間もコストもかかり大変であ る. 海水は現地水盤から採取してからの経過時間や運搬 時の振動によって, 塩分量や塩分量の分布形が変化する ため, 可能な限り現地で行うことが望ましい. しかし寒 冷地の辺地での試験には多くの困難が伴う.コンクリー トの場合には過去に行われた多くの研究成果に基 づいて，各強度間の関係が明らかになっているの で, 強度の判定にあたっては，一軸圧縮強度試験 を行うことによって他の強度も推定が可能となっ ている ${ }^{37)}$. 海氷においても各強度間の関係が明ら かになっていると非常に便利であり, 工学上有意 義である. コンクリートの場合, 砂利, 砂, セメ ントそれに水などの配合を任意に選択できるが, 海水の場合は気象や海象条件によって海水の組成 も微妙に異なることになるのでその点がやっかい である，同一の水塊を用い，決められた試験方法 で強度相互の関係を調べた研究はきわめて少な い. 図一15に佐伯らの一軸圧縮強度 $\sigma_{c}$ と曲げ強 度 $\sigma_{f}$ の関係を示す ${ }^{20)}$. 一軸圧縮強度試験は径 10 $\mathrm{cm}$, 高さ $20 \mathrm{~cm}$ の円筒供試体を用い, ひずみ速 


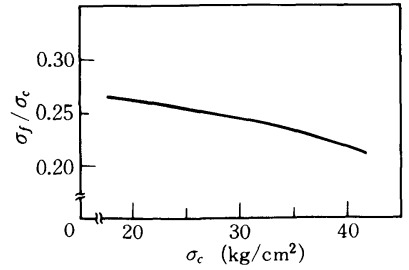

図一15一軸圧縮強度と曲げ強度の関係 (Saeki et al. 1978)

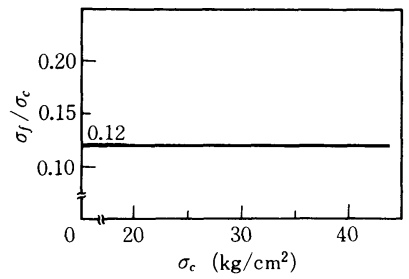

図一16 海氷の一軸圧樎強度と引張強度の関係 (Saeki et al. 1978)

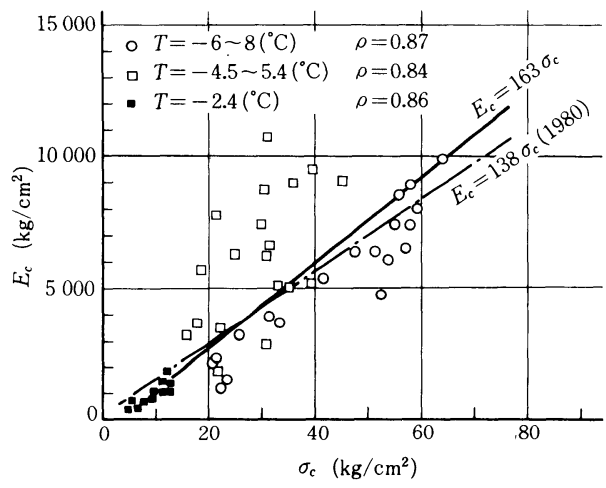

図一17 海米の圧縮弾性率と一軸圧縮強度の関係

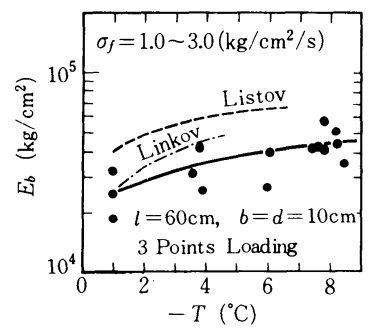

図一18 海氷の曲げ弾性率と水温の関係 (Saeki et al. 1982)

度 $\dot{\varepsilon}$ は最大の強度を示す $\dot{\varepsilon}=10^{-3} \sim 3 \times 10^{-3} \mathrm{~s}^{-1}$ で武験を 行った. また曲げ強度も最大の強度を示すひずみ速度 $\dot{\varepsilon}_{f} \doteqdot 10^{-3} \sim 3 \times 10^{-3} \mathrm{~s}^{-1}$ で, 供試体寸法はスパン長 $40 \mathrm{~cm}$, 高さ $10 \mathrm{~cm}$, 幅 $10 \mathrm{~cm}$ で試験を行っている. 一軸圧縮強 度 $\sigma_{c}$ の増加とともに, 両強度の比 $\sigma_{f} / \sigma_{c}$ は小さくなっ ている.コンクリートに対する Graf の結果によれば37, $\sigma_{f} / \sigma_{c}$ は $0.24 \sim 0.21$ の範囲で, 海水の場合と非常に似 かよった変化を示している. また，佐伯らは引張強度に ついても特殊な形状の供試体と固定治具を用いて, 最大 の強度を示す応力速度で求めた引張強度 $\sigma_{t}$ と $\sigma_{c}$ の関係 を調べたものが図一16である20). 図からも明らかなよ うに, $\sigma_{t} / \sigma_{c} \doteqdot 0.12$ とほぼ一定値を示すが, Gonnerman や狩野のコンクリートでの結果 ${ }^{37)}$ では $0.07 \leqq \sigma_{t} / \sigma_{c} \leqq 0.12$ で両材料の $\sigma_{t} / \sigma_{c}$ は比較的近い値を示している. また海 水のせん断強度 $\tau_{s}$ の場合は $\tau_{s} / \sigma_{c} \doteqdot 0.21$ であるのに対 し ${ }^{20)}$, コンクリートの場合は $\tau_{s} / \sigma_{c} \doteqdot 0.23$ となってい $3^{37)}$. 以上の結果をみる限り, 各強度間の関係は海水亡 コンクリートでは非常に似かよった傾向を示している. しかし, その後の佐伯らの研究によると水質によって各 強度間の関係は少しずつ異なることが明らかにされ，今 後この面からの研究が望まれる.

\section{（6） 海氷の弾性定数}

海水の場合も, 他の材料之同様に圧縮弾性率 $E_{\mathrm{c}}$ と曲 げ弾性率 $E_{b}$ は異なった值を示す。両弾性率とも, 強度 の場合と同様にひずみ速度や応力速度に依存していて， ひずみ速度では $10^{-3} \mathrm{~s}^{-1}$ 近傍で, 応力速度では $1 \sim 20$ $\mathrm{kg} / \mathrm{cm}^{2} / \mathrm{s}$ で最大の值を示す．佐伯らの結果によると圧 縮弾性率 $E_{c}$ については図一17 に示すように, デー夕の 分散は大きいが $E_{c}$ と一軸圧縮強度 $\sigma_{c}$ の間には, $E_{c}=138 \sim 163 \sigma_{c}$ の関係がある. 前にも述べたように一 軸圧縮強度 $\sigma_{c}$ は塩分量, 密度それに水温に依存してい ることから $E_{c}$ も当然それらに依存していることにな る. 次に, オホーツク海の海水の曲げ弾性率 $E_{b}$ 亡水温 の関係を图一18 に示す ${ }^{39}$. Listov のデータはラプチェ フ海の海水で地震法によって求めたものであり, Lin'kov の場合は，シベリヤのシュミット岬の近くの海 水で地震法で求めたもので, 佐伯らの結果より大きい曲 げ弾性率を示している.一般に海氷の強度や弾性定数(弾 性率やポアソン比）については, 動的方法で求めた値の 方が静的方法で求めたものより大きい值を示すし, Lin'kov や Listov は高緯度の海水を用いていて, 空気 量の少ない海水であることが想像される. 海水の弾性率 については，動的手法によるものと，ひずみ量あるいは たわみ量から求める静的手法による 2 種類の方法で求め られるが, 静的手法により求められる弾性率の方が実用 的であると思われるが, 今後は両方法で得られる弾性率 の関係を明確にする必要があると思われる．次に海水の ポアソン比ンについては Oliver, Crary \& Cotell10) $の$ 北極海の Pack Ice での地震法による測定結果によると $\nu=0.32 \sim 0.37$ となり, Peshanskyによると $\nu=0.29$ で ある ${ }^{41)}$. オホーツク海の海水については石田が振動法に $\nu=0.38$ の値を得ている ${ }^{42), 43)}$. これに対して佐伯らは Poisson Gage を開発し，円筒供武体の一軸圧縮試験に 


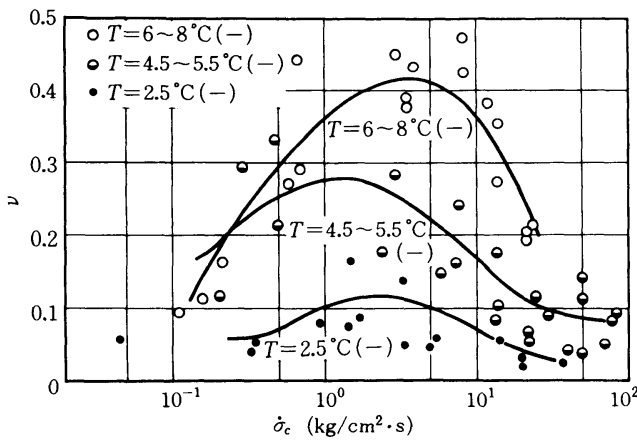

図一19 海氷のポアソン比と水温と応力速度の関係 (Saeki et al.1981)

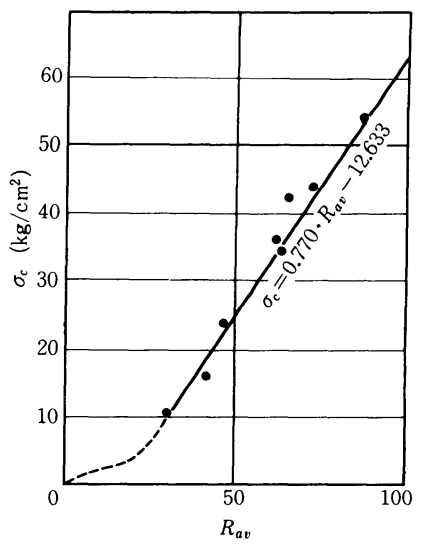

図一20 シュミットハンマー (PT 型) の反発硬度と

一軸圧縮強度の関係（Tsutae et al. 1983）

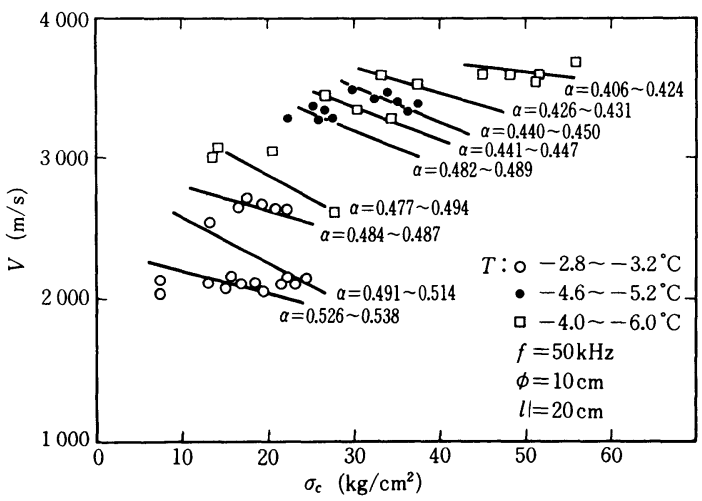

図一21 海米の一軸圧樎強度と超音波の音速と娍表定数の関係 (Saeki et al. 1984)

よりポアンン比 $\nu$ を求めている ${ }^{36), 38)}$. その結果が図一 19 であるが, ポアソン比は水温と応力速度 $\dot{\sigma}_{c}$ に依存し, $\dot{\sigma}_{c}=1 \sim 10 \mathrm{~kg} / \mathrm{cm}^{2} / \mathrm{s}$ で最大のポアソン比を示すし, 水 温が低いほど, 応力速度 $\dot{\boldsymbol{\sigma}}_{c}$ の影響を強く受ける. 以上 の結果から, 強度, 弾性率それにポアンン比はひずみ速
度および応力速度の影響を受け, ひずみ速度が $10^{-3} \mathrm{~s}^{-1}$ のオーダーで, 応力速度が $1 \sim 20 \mathrm{~kg} / \mathrm{cm}^{2} / \mathrm{s}$ の範囲でそ れぞれ最大値を示すことが明らかになっている.これら の値を現実の問題に用いる場合には十分注意しておくこ とが必要である。

\section{（7）海水強度の简易測定法}

海水の強度をより簡単な方法で知ることができるなら ば，実際の水盤の強度に関するデー夕も広範用に多量に 集めることが可能となり,構造物の設計に大いに役立つ. 前にも述べたように，単純で，軽量で，現地で測定でき るような強度試験法が開発されることが期待されてい る. Gerard は，Windsor 打込針装置を用いた強度の推 定法を提案している ${ }^{44)}$. Tsutae らはPT 型のシュミッ トハンマーの反発硬度 $R_{a v}$ から海水強度を求める手法 を開発した ${ }^{45)}$. その結果を図一20に示す. 反発硬度と 一軸圧縮強度（径 $10 \mathrm{~cm}$, 高さ $20 \mathrm{~cm}$ の円筒供試体でひ ずみ速度 $10^{-3} \sim 3 \times 10^{-3} \mathrm{~s}^{-1}$ で求めた強度）の関係は次 式で示される.

$$
\sigma_{c}=0.770 \cdot R_{a v}-12.633 \quad R_{a v} \geqq 30
$$

この式は 9 種類の塩分量, 水温それに密度の異なってい る海水から求めたものであるが，このシュミットハン マ一の打撃による方法は, 水盤の表面の強度が強く反発 硬度に影響を与えることが予測される．佐伯らは皮盤の 平均的な強度を求める手法として, 超音波の海水中の音 速と, 减衰定数 $\alpha$ から一軸圧縮強度を判定する方法を 提案した ${ }^{46)}$. 棒状の供試体中の音速 $V$ は海水の弾性率 と密度を $E$ と で表わすと次式で示される.

$$
V=\sqrt{\frac{E}{\rho}}
$$

また，減衰定数 $\alpha$ は次式で示される.

$$
P_{l}=P_{0} \cdot \exp (-\alpha \cdot l) \text {. }
$$

$P_{0}$ は発振子の音圧, $P_{l}$ は距離 $l$ 離れた点の受振子の音 圧である， $\sigma_{c}$ と $V$ と $\alpha$ の関係を図一21に示す．このと きの一軸圧縮強度 $\sigma_{c}$ はシュミットハンマーの場合と同 じ手法で求めたものである. 図からも明らかなように音 速 $V$ の増加とともに強度 $\sigma_{c}$ は大きくなるが, 減衰定数 aが与えられて, 強度が確定することになる．この手法 は開発途上であるため，この試験では氷の供試体を発振 子と受振子ではさんでいるが，現実の水盤から直接，強 度を推定するためには氷盤の下面での音波の反射率を明 確にする必要がある. 以上述べた海水強度の簡易推定法 はすべて開発途中であり，より精度のよい簡単な強度判 定法の開発が望まれている.

\section{4. 結論}

以上, 海水の結水機構と強度特性についての最近の研 究動向について述べてきた。この海氷の問題は, 最終的 
には氷海域における各種構造物の設計，施工あるいは， 海岸環境の保全にとって重要な課題である。しかし海水 に対する工学の面からの研究の歴史は浅く，そのため今 後に残された課題は多い. 海水の結水機構については, 海水の物性および氷厚の予測が最終的な目的であるが, そのためには，(1)実際の海水の水厚分布および組成の観 測結果が非常に少ない。これは寒冷であるという気象的 な条件と，辺地であるという不便さのためである．これ を解決するためには, 最終的には, リモートセンシング 技術の応用を考えるべきである. (2)実際の海水は平坦な 水平水だけではなく, 氷脈 (Ice Ridge) や重なり合っ た海水盤（Rafted Ice）があり，構造物の設計等にとっ ては，このような海水の方がより重要ともいえる．この ような海水の成生機構の解明も重要である. (3)海水は常 に変形, 移動している. 海水の結水機構と同様に海水盤 の変形, 移動機構の解明も必要である. (4)最近, 海水之 構造物や船舶間の相互作用に関する模型実験が行われて きているが, 模型実験で最も困難な課題は, 任意の強度 と弾性定数の海水を造る技術である. 海水の結水機構の 解明を前進させて, 模型水の製造技術の開発も重要であ る. (5)寒冷地における海面および氷盤面と大気間の熱交 換過程の解明は結水開始日, 解水日の予測と水厚予測に 重要であるが, 今後は降雪の効果も考慮すべきである.

また, 海氷の強度特性について今後解明せねばならな い課題を列挙すると, (1)海水の組成 (塩分量, 密度, 水温) と結晶構造と海水の強度の関係をより明確にすること.

(2)海水は粘弾性体であるが，海水の粘弾性体としての取 り扱い方法を確立すること. (3)海水の強度試験方法の確 立を急ぐとともに，各海域別の強度特性を明らかにする こと. (4)各強度間の関係を明確にすること. (5)平坦な Level Ice だけでなく, Ice Ridge 等の強度特性も明ら かにすべきであること. 6)今までは一部の研究者でしか 行われていなかった，二軸あるいは三軸応力条件下の海 氷の強度特性を明らかにすること. (7)広い海域の海水の 強度を測定できるような非接触型の強度測定技術の開 発.

以上, 海水の結水機構, それに強度特性に関しては, 今後解決すべき問題は多い。わが国の水工学の技術と知 識が寒冷地の海岸, 海洋の問題の解決に積極的に活用さ れる時代が来ることを願ってやまない.

\section{参 考 文 献}

1) V.V. シュレイキン：海洋の分子物理学, ラティス, pp. $92 \sim 99$.

2) Schwarz, J. and Weeks, W. F. : Engineering Properties of Sea Ice, Jour. of Glaciology, Vol. 19, No. 81, pp. 499 $\sim 530,1977$.

3) Stefan, J. : Ueber die Theorie der Eisbidung, insbeson- dere uber die Eisbildung in Polarmeere, Sitzungsberichte Wien. Akad, Wiss. A., 98, 965, 1890.

4）川下研介：熱伝導論, 河出書房, pp. 416 421, 1941 .

5）福富孝治・楠 宏・田畑忠司：海水の研究（第 6 報）海 氷の水厚増加に就いて, 低温科学, $3,169,1950$.

6) Tabata, T. : On the Formation and Growth of Sea Ice expecially on the Okhotsk Sea. Arctic Sea Ice, pp. 169 $180,1958$.

7) Zubov, N. N. : Arctic Ice, p. 491, 1943.

8) Malmgren, F. : On the Properties of Sea Ice, The Norwegian North Polar Expedition with "Maud", Sci. Results, 1 ( 5 ), p. 67,1927 .

9）小野延雄：海水の熱的性質の研究IV. 海水の熱的諸定数, 低温科学, 物理篇, 26, pp. 329 349, 1968.

10) Kolesnikov, A. G. : On the Growth of Sea Ice, Nut. Acad. Sci., Nat. Res. Council, U.S. A., Pub. 598, pp. 157 161, 1958.

11) Maykut, G. A. and Untersteiner, N. : Numerical Prediction of the Thermodynamic Responce of Arctic Sea Ice to Environmental Changes, The Rand Corporation, Memorundum RM-6039-PR, p. 166, 1969.

12) Maykut, G. A. and Untersteiner, N. : Some Results from a Time-dependent Thermodynamic Model of Sea Ice, Jour. of Geophysical Res., Vol.76, pp.1550 $1575,1971$.

13）長谷美達雄：薄い一冬水の成長について, 低温科学, 物 理篇, 第 32 号, pp. 207 218, 1974.

14) Weeks, W. F. and Lofgren, G. : The Effective Solute Distribution Coefficient during the Freezing of $\mathrm{NaCl}$ Solutions, Physics of Snow and Ice, Institute of Low Temperature Science, Hokkaido Univ., Vol. 1, No. 1, pp. $579 \sim 597,1967$.

15）青田昌秋・田畑忠司：北海道オホーツク海沿岸の水高分 布, 低温科学, 物理篇, 第 39 輯, pp. 141 151, 1980.

16) Hibler, W. D. : Removal of Aircraft Altitude Variation from Laser Profiles of Arctic Ice Pack, Jour. of Geophysical Res., Vol. 77, pp. 7190 7195, 1972.

17) International Association of Hydraulic Research, Committee on Ice Problems : Report of Task-Committee on Standardizing Testing Methods for Ice, Proc. The Third International Symposium on Ice Problems, pp.607 $611,1975$.

18) IAHR-Working Groupe on Standardizing, Ed. by J. Schwarz : IAHR-Recommendations on Testing Methods of Ice Properties, Division of Water Resources Engineering, Univ. of Lulea, Bulletin Series, A, No. 24, 1978.

19) Saeki, H., Saito, S., Hamanaka, K. and Ozaki, A. : Experimental Study on the Compressive Strength of Sea Ice and the Ice Forces on an Circular Pile, Coastal Engineering in Japan, Vol. 19, pp. 73 87, 1976.

20) Saeki, H., Nomura, T. and Ozaki, A. : Experimental Study on the Testing Methods of Strength and Mechanical Properties for Sea Ice, Proc. IAHR Symposium on Ice Problems, Part 1, pp. 135 149, 1978. 
21) Frederking, R. and Häusler, F. U. : The Frexural Behavior of Ice from In-situ Cantilever Beam Test, IAHR Symposium on Ice Problems, Lulea, 1978.

22) Lavrov, V. V. : The Nature of the Scale Effect in Ice and the Strength of an Ice Cover, Doklady Akademiia Nauk SSSR, Vol.122, pp. 570 573, 1958.

23）平山健一・赤松久生・近藤 肇：淡水水の曲げ強度にお ける供試体の大きさの効果について, 土木学会第 33 回年 次学術講演会概要集, II, p. 700, 1979.

24) Weeks, W. F. and Assur, A. : Fracture of Lake and Sea Ice, U.S. Cold Regions Res. and Eng. Lab., Res. Report 296, 1969.

25）近藤連一編：多孔材料, 技報堂出版, pp. 165 183, 1973.

26) Reyton, H. R. : Sea Ice Strength, Geophysical Institute, Univ. of Alaska, Report No. NR-307-247/7-6-55, pp. 1 273, 1966.

27) Schwarz, J. : The Pressure of Floating Ice-Field on Piles, IAHR Symposium, Ice and Its Action on Hydraulic Structure, 1970.

28) Korzhavin, K. N. : The Effect of Local Crushing on the Mechanical Properties of River Ice, Tr, TransportnoEnergeticheskogo Inśtitut, Vol. 11, pp. 13 23, 1961.

29) Carter, D. and Michel, B. : Lois et Méchanis̀mes de Lápparente Fracture'Fragile! de la Glace de Rivière et de Lac, Univ. Laval, Faculté des Sciences, Départment de Genie Civil, Rep. S-22, 1971.

30) Frederking, R. M.W. : Preliminary Results of Plane Strain Compression Tests on Columnar-Grained Ice, IAHR Symposium, Ice and Its Action on Hydraulic Structures, pp. 26 29, 1972.

31) Gold, L. W. and Krausz, A.S. : Investigation of the Mechanical Properties of St. Lawrence River Ice, Canadian Geotechnical Journal, Vol.8, No.2, pp. 163 $169,1971$.

32) Mellor, M. and Smith, J. H. : Creep of Snow and Ice, Proc. of Physics of Snow and Ice, Vol. 1, Pt.2, pp. 843 $\sim 855,1967$.

33) Michel, B. and Toussaint, N. : Mechanisms and Theory of Indentation of Ice Plates, Jour. of Glaciology, Vol. 19, No. 81, pp. 285 300, 1977.

34) Schwarz, J. and Weeks, W. F. : Engineering Properties of Sea Ice, Jour. of Glaciology, Vol. 19, No. 81, pp. 499
$-530,1977$.

35) Dykins, J. E. : Tensile Properties of Sea Ice Grown in a Confined System, Proc. of Physics of Snow and Ice, Institute of Low Temperature Science, Hokkaido Univ. , Vol. 1, No. 1, pp. 523 537, 1967.

36) Saeki, H., Ozaki, A. and Kubo, Y. : Experimental Study on Flexural Strength and Elastic Modulus of Sea Ice, Proc. of 6th International Conference on Port and Ocean Eng. under Arctic Conditions, 1981.

37）近藤泰夫・坂 静雄：コンクリート工学ハンドブック, 朝倉書店, pp. 276 328, 1965.

38）佐伯 浩- 西谷一典 - 小野敏行 - 金 洸洛 - 尾崎 晃 : 海水の弾性定数亡水盤の耐荷力について, 第 27 回海岸工 学講演会論文集, pp. 353〜357, 1980.

39）佐伯 浩 - 田中祐人 - 酒井雅史 - 小野敏行 - 尾崎 晃 : 水盤凍着に伴う直立杭構造物に作用する軸方向水力につ いて, 第 29 回海岸工学講演会論文集, pp. 482 485, 1982.

40) Oliver, J., Crary, A. P. and Cotell, R. : Elastic Waves in Arctic Pack Ice, Trans. American Geophysical Union, Vol. 35, 282, 1954.

41) Peschansky, I. S. : Physical and Mechanical Properties of Arctic Ice and Method of Research, Proc. Arctic Sea Ice Conference, National Research Council, Pub. 598, pp. $100 \sim 104,1958$.

42) Ishida, T. : Velocity of Elastic Waves in Ice, Low Temperature Science, A. 17, pp. 99 107, 1958.

43) Ishida, T. : Propagation of Elastic Waves in Sea Ice, Low Temperature Science, A. 18, pp. 157 169, 1959.

44) Gerard, R. : A Simple Field Measure of Ice Strength, Proc. of 3rd International Symposium on Ice Problems, pp. $589 \sim 600,1975$.

45) Tsutae, S., Itoh, Y., Izumi, K., Ono, T. and Saeki, H. : Estimation of the Compressive Strength of Sea Ice by the Schmidt Test Hammer, Proc. of 7th International Conf. on Port and Ocean Eng. under Arctic Conditions, Vol. 2, pp. 1080 1090, 1983.

46) Saeki, H., Ono, T., Nakazawa, N., Izumi, K. and Sakai, M. : Determination of Compressive Strength of Sea Ice by Using an Ultrasonic Pulse, Proc. of IAHR Ice Symposium, Vol. 2, pp. 339 348, 1984.

(1985.4.22 - 受付) 